\title{
PELATIHAN PENINGKATAN PENGETAHUAN KEWIRAUSAHAAN KEPADA PENGELOLA KOPERASI USAHA DI KOTA TANGERANG
}

\author{
Nila Krisnawati ${ }^{1}$, Alfiandri ${ }^{2}$ \\ ${ }^{1}$ Universitas Swiss Jerman
}

nila.hidayat@sgu.ac.id, alfiandri@sgu.ac.id

\begin{abstract}
Abstrak
Sebagai salah satu rekomendasi dari kegiatan penelitian tentang peningkatan kinerja koperasi di Tangerang yang dilaksanakan pada tahun 2018, maka diperlukan suatu pelatihan tentang kewirausahaan kepada pengelola koperasi usaha yang berdampak pada peningkatan keterampilan manajerial para pengelola koperasi sehingga mampu mengembangkan unit usahanya secara optimal. Untuk itu pada bulan Februari 2019, telah dilakukan kegiatan pengabdian masyarakat berupa pelatihan dasar kewirausahaan serta implementasinya pada operasional usaha kepada tiga puluh lima pengurus koperasi usaha di Kota Tangerang, yang difasilitasi oleh Dinas Koperasi dan Usaha Kecil Menengah (UKM) Kota Tangerang. Kegiatan ini bertujuan untuk mengembangkan dan meningkatkan jiwa kewirausahaan pengelola koperasi termasuk pelaku usaha kecil binaan koperasi di Kota Tangerang, sekaligus menawarkan solusi atas permasalahan yang dialami oleh para pengelola koperasi yaitu masih rendahnya kinerja koperasi yang salah satu nya disebabkan oleh lemahnya pemahaman dan pengetahuan tentang kewirausahaan dalam rangka mengoptimalkan penghasilan koperasi. Pelatihan dilakukan dalam bentuk ceramah serta diskusi mendalam tentang permasalahan teknis dan bagaimana solusi mengatasinya. Melalui kegiatan ini diharapkan pengelola koperasi usaha dapat mengembangkan unit usahanya sehingga dapat meningkatkan keuntungan serta berdampak positif terhadap peningkatan kinerja koperasi usaha kota Tangerang.
\end{abstract}

Kata kunci: Koperasi usaha, Kewirausahaan, Operasional Usaha, Kinerja.

\section{PENDAHULUAN}

Sebagai salah satu upaya meningkatkan perekonomian nasional agar terus tumbuh dan berdampak pada pemerataan kesejahteraan, maka keberadaan koperasi perlu dioptimalkan pada setiap kegiatan produksi masyarakat Indonesia. Untuk mewujudkan hal tersebut, maka koperasi harus mampu bekerja seefisien mungkin dan menjalankan prinsip dan kaidah ekonomi. Pertumbuhan koperasi sebagai sekelompok orang dengan tujuan mencapai kesejahteraan di antara para (Dr. Subandi, 2017), adalah sebagai bagian dari Usaha Kecil Menengah (UKM) di Indonesia dapat dikatakan cukup baik. Akan tetapi perolehan nilai tumbuh produk UKM hanya $3.40 \%$, jauh tertinggal dibanding perusahaan berskala besar yaitu mencapai $96,5 \%$ (Kementerian 
Luar Negeri, 2013). Salah satu penyebab dari kondisi ini adalah masih belum merata nya kualitas UKM termasuk di dalamnya adalah koperasi. (Andiningtyas, 2014). Untuk itu kualitas koperasi menjadi prioritas utama yang harus ditingkatkan serta keberadaan sumber daya manusia yaitu pengelola koperasi yang turut berperan dalam pengembangan kualitas tersebut. Hal yang sama disampaikan pula oleh Syarifudin Kepala Bidang Koperasi Dinas Koperasi dan UKM Kota Tangerang (Syarifudin, 2018) bahwa terdapat 712 koperasi yang masih aktif beroperasi di Kota Tangerang. Namun jumlah tersebut mengalami penurunan akibat permasalahan internal terkait tata kelola dan sumber daya manusia serta dampak dari perkembangan perusahaan retail dan minimarket. Jumlah koperasi di Tangerang mengalami pertumbuhan sebagaimana yang ditampilkan pada tabel berikut :

Tabel 1. Jumlah Koperasi di Kota Tangerang 2014-2016

\begin{tabular}{cccc}
\hline Koperasi & 2014 & 2015 & 2016 \\
\hline Aktif & 647 & 669 & 655 \\
Non-Aktif & 402 & 307 & 337 \\
Total & 1049 & 976 & 992
\end{tabular}

Sumber : BPS, Kota Tangerang 2017

Berdasarkan tabel 1 di atas, dapat disimpulkan bahwa jumlah koperasi aktif meningkat, akan tetapi jumlah yang non-aktif pun mengalami peningkatan hingga tahun 2016 sebesar 337 unit.(BPS Kota Tangerang, 2017). Pada penelitian yang dilakukan oleh (Krisnawati \& Alfiandri, 2019) salah satu penyebabnya adalah keberadaan sumber daya manusia yang masih belum optimal.

Keberadaan sumber daya manusia menjadi sangat penting dan berdampak pada kinerja koperasi disampaikan pula (Lai, Saridakis, \& Johnstone, 2017). Peran SDM tersebut selain sebagai pengelola dan administrasi yang mengendalikan operasional usaha. Untuk itu dibutuhkan pemikiran dan keterlibatan penuh baik dari segi pemikiran maupun keterampilan pengelola termasuk dalam menggerakan anggotanya. Sebagaimana penelitian yang diungkap (Dessler, 2015), keberadaan tim sumber daya manusia dalam perusahaan termasuk koperasi adalah terkait dengan pengembangan staf yang ada didalamnya yaitu dengan melatih, menilai, dan memberikan kompensasi kepada karyawan, serta untuk menjaga kesehatan dan keselamatan mereka.

Berdasarkan penelitian (Krisnawati \& Alfiandri, 2019), salah satu cara untuk meningkatkan jumlah usaha di Indonesia umumnya dan di Kota Tangerang adalah dengan meningkatkan pengetahuan dan ketrampilan kewirausahaan, sehingga koperasi mampu bersaing dengan dengan semakin pesatnya pertumbuhan modern ritel.

Untuk itu, maka Fakultas Bisnis dan Komunikasi Universitas Swiss Jerman menjalankan kegiatan Pengabdian Kepada Masyarakat (PKM) melalui Pelatihan Peningkatan Pengetahuan Kewirausahaan Kepada Pengelola Koperasi Usaha Di Kota Tangerang pada tanggal 26 Februari 2019.

\section{METODE}

Pelatihan dilakukan pada tanggal Februari 2019 yang diikuti oleh 35 (tiga puluh lima) peserta koperasi usaha yang direkomendasikan oleh Dinas Koperasi Kota Tangerang.

Adapun metode yang digunakan adalah dengan melakukan penggabungan beberapa pendekatan pembelajaran yang efektif dengan tujuan agar peserta dapat menyerap materi dalam upaya peningkatan pengetahuan, keterampilan dan perilaku terkait kewirausahaan. Metode utama yang diterapkan adalah metode ceramah. Hal ini dimaksudkan agar peserta dapat langsung menerima dan memahami materi langsung dari narasumber. Metode ceramah ini bertujuan untuk :

1) Memberikan pemahaman terkait konsep wirausaha, unsur-unsur harus diperhatikan dan bagaimana mengatasi kendala baik terkait dengan hal teknis maupun sumber daya manusia nya.

Ekonomi, Sosial, dan Budaya

1460 
2) Peserta mendapatkan gambaran proses wirausaha dari kondisi awal, perjalanan jaruh bangun hingga keberlanjutan suatu usaha.

Metode lainnya yang diterapkan adalah melakukan diskusi serta kuis ringan dengan memberikan pertanyaan kepada peserta terkait materi yang diberikan. Melalui metode ini, tim pelaksana pelatihan mendapatkan gambaran dan analisa dasar terhadap tingkat penyerapan dan pemahaman peserta tentang materi kewirausahaan.

\section{HASIL DAN PEMBAHASAN}

\section{Persiapan Pelaksanaan}

Persiapan program pelatihan dilakukan selama kurang lebih 2 (dua) minggu, meliputi ; konfirmasi dengan pihak dinas koperasi Tangerang baik terkait dengan tempat maupun jumlah peserta pelatihan.

\section{Pelaksanaan}

Kegiatan pelaksanaan dilaksanakan pada hari Selasa, 26 Februari 2019 dengan peserta berjumlah 35 orang peserta. Peserta adalah pengelolaa koperasi usaha yang direkomendasikan oleh Dinas Koperasi Kota Tangerang. Profil peserta mayoritas adalah Ibu Rumah Tangga yang baru memiliki pengalaman singkat selama kurang lebih 1 (satu) tahun dalam mengelola koperasi usaha.

Acara didahului dengan pembukaan yang disampaikan oleh Bapak Syarifudin selaku Kepala Bidang Koperasi Kota Tangerang. Adapun susunan acara pelatihan kewirausaaan adalah sebagai berikut;

Tabel 2. Susunan Acara

\begin{tabular}{cc}
\hline Koperasi & Acara \\
\hline $08.00-08.30$ & Pendaftaran Peserta \\
$08.30-08.35$ & Pembukaan Acara Pelatihan oleh MC \\
$08.35-08.50$ & Pembukaan dan Pengarahan dari Kabid \\
& Koperasi Kota Tangerang \\
$08.50-11.50$ & Sessi $1:$ Konsep dan Dasar-Dasar Manajemen \\
$11.50-13.50$ & Kewirausahaan \\
$13.50-14.50$ & ISOMA \\
$14.50-15.30$ & Sessi II : Meningkatkan Ketrampilan Pengelola \\
$15.30-15.40$ & Koperasi Usaha \\
& Tanya Jawab \\
\hline
\end{tabular}

Acara dimulai tepat waktu dan seluruh peserta serta nara sumber pun sangat antusias dalam program pelatihan tentang kewirausahaan ini. Tim nara sumber yang bertugas dari Universitas Swiss Jerman terdiri dari; Dr.Nila Krinawati dan Alfiandri, SE.M.Sc. Adapun profil peserta adalah sebagai berikut;

Tabel 3. Profil Peserta Pelatihan

\begin{tabular}{|l|c|c|}
\hline \multicolumn{1}{|c|}{ Tipe Koperasi } & Frequency & Percent \\
\hline Koperasi Usaha & 35 & 100 \\
\hline \multicolumn{1}{|c|}{ Posisi } & & \\
\hline Manajer keuangan & 3 & 8.6 \\
Staf Admin & 18 & 51.4 \\
Lainnya & 14 & 40 \\
\hline$\quad$ Lama Bekerja & & \\
\hline Kurang dari 2 thn & 23 & 65.7 \\
2-5 thn & 6 & 17.1 \\
6-10thn & 6 & 17.1 \\
\hline \multicolumn{1}{|c|}{ Pendidikan } & & \\
\hline Sarjana S2 & 6 & 17.2 \\
Sarjana S1 & 12 & 34.3 \\
Diploma & 17 & 48.6 \\
\hline
\end{tabular}

Sumber : Survei, 2019



Gambar 1. Fasilitator PKM Koperasi Kota Tangerang

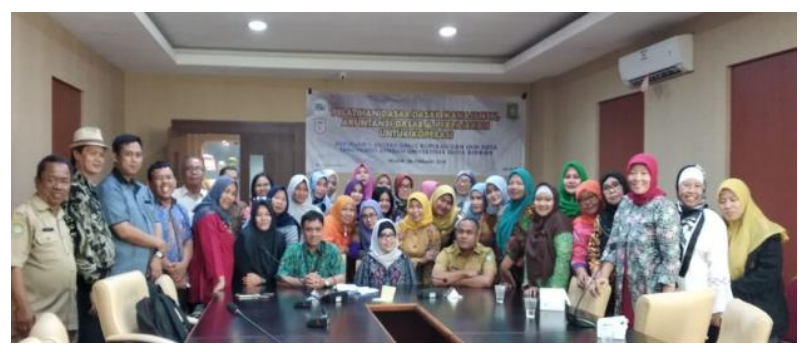

Gambar 2. Peserta Pelatihan dan Kabid Koprasi Kota Tangerang

Ekonomi, Sosial, dan Budaya 


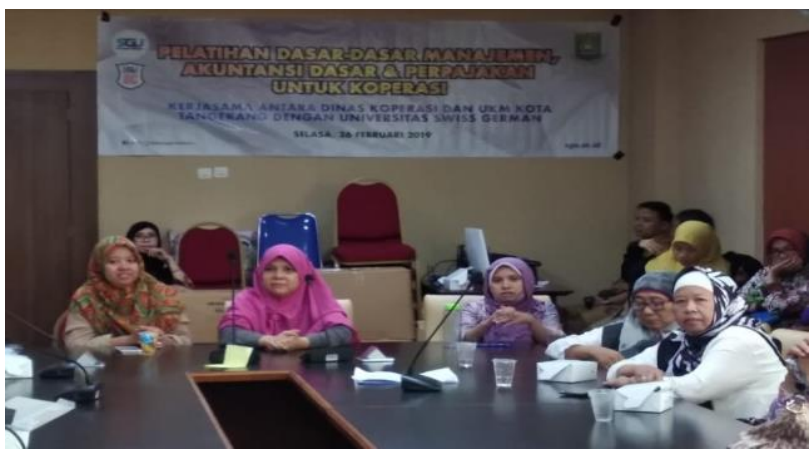

Gambar 3. Peserta Pelatihan Mendengarkan Ceramah yang disampaikan Narasumber dari Swiss German University (SGU)

\section{Evaluasi}

Hasil evaluasi yang dapat disimpulkan meliputi ;

1) Melalui kuesioner yang diberikan kepada para peserta, hasilnya adalah $98 \%$ merasakan sangat puas dan menyatakan manfaat dari program pelatihan ini. Demikian pula penilaian terhadap para fasilitator dari Universitas Swiss Jerman sangat memadai dari segi kompetensi dan penyampaian materi juga menyenangkan dan dapat dimengerti dengan baik oleh para peserta.

2) Dari perspektif para fasiltator Universitas Swiss Jerman, peserta dinilai sangat antusias dengan melakukan observasi sederhana terhadap proses belajar dimana seluruh peserta memperhatikan dengan serius dan seksama, beberapa dari mereka melakukan pencatatan pada buku masing-masing. Selain itu, pertanyaan dalam kuis juga dapat dijawab dengan baik oleh para peserta.

3) Diperlukan pendampingan secara berkala bagi para pengelola koperasi, agar fungsi usaha koperasi ini dapat berjalan dengan lebih baik lagi. Aspek-aspek yang perlu mendapat perhatian antara lain pemberdayaan sumber daya manusia, khususnya pengelola dan tenaga administrasi. Tidak sedikit dari para pengelola yang sebenarnya adalah pegawai atau staf yang bekerja pada perusahaan lain, sehingga dari segi waktu mereka menghadapi kendala.
4) Pelatihan tentang peningkatan ketrampilan dalam mengelola usaha koeprasi juga perlu dilaksanakan, bekerjasama dengan dinas Dinas Koperasi Tangerang serta lembaga pendidikan tinggi.

5) Aspek lain yang perlu mendapatkan perhatian adalah meliputi peningkatan kapasitas koperasi dalam menggunakan layanan teknologi informasi. Keberadaan IT akan sangat membantu proses usaha koperasi dalam meningkat kan kinerja nya.

\section{KESIMPULAN}

Program PKM Pelatihan Peningkatan Pengetahuan Kewirausahaan Kepada Pengelola Koperasi Usaha Di Kota Tangerang pada tanggal 26 Februari 2019 merupakan upaya proaktif dan wujud kepedulian Fakultas Bisnis dan Komunikasi Universitas Swiss Jerman untuk membantu pemerintah dalam meningkatkan kesejahteraan masyarakat, khususnya koperasi usaha di kota Tangerang. Seluruh peserta program ini mendapatka wawasan pengetahuan yang baik terkait konsep dasar dan aplikasi kewirausahaan yang diperlukan untuk pengembangan usaha koperasi pada ma yang akan datang. Melalui program ini, diharapkan terjadi kolaborasi kemitraan yang baik anatara pemerintah dan lembaga pendidikan tinggi dalam melakukan peningkatan kualitas SDM khusus nya pengelola koperasi. Dalam jangka panjang target dan sasaran yang diharapkan adalah mewujudkan masyarakat madani dengan peningkatan kualitas hidup, kemandirian dan kesejahteraan.

\section{UCAPAN TERIMAKASIH}

Ucapan terimakasih disampaikan kepada Dinas Koperasi Kota Tangerang Tangerang, yang telah memfasilitasi dengan sangat baik pada program PKM Pelatihan Peningkatan Pengetahuan Kewirausahaan Kepada Pengelola Koperasi Usaha. 


\section{REFERENSI}

Andiningtyas, I. (2014). Pengaruh Orientasi Kewirausahaan Terhadap Kinerja Perusahaan Kecil. Jurnal Manajemen Indonesia, 14 (1).

Ardianti, R. (2009). Entrepreneurship Education in Indonesia's Higher Education Institutions ; A Solution for Problems Faced by The Next Generation. London International Conference on Education (LICE), UK .

Dessler, G. (2015). Human Resource Management (14th ed.). England: Pearson Education Limited

Lai, Y., Saridakis, G., \& Johnstone, S. (2017). Human Resources Practices, Employee Attitudes and Small Firm Performance. International Small Business Journal , 470-494

Krisnawati, N., \& Alfiandri. (2019). Assesment of Factors Influencing Cooperatives Performance. Journal of Entrepreneurs, Business and Economics , 7 (2), 80-105.

Kementerian Luar Negeri. (2013).

Miyazaki, H., \& Neary, H. M. (1983). The Illyrian Firm Revisited. The Bell Journal of Economics , 259-270.

Syarifudin. (2018, Februari). Retrieved from tangerangnews.com.

Santoso, I., Yuwandini, D., \& Mustaniroh, S. A. (2015). Pengaruh Kredit Dan Sumber Daya Manusia Terhadap Kinerja UMKM Agroindustri Dengan Pemasaran Sebagai Variabel Antara. Jurnal Manajemen \& Agribisnis , 174-182.

Subandi. (2017). Pengolongan Koperasi Berdasarkan Bidang Usaha. In Riduwan (Ed.), Ekonomi Koperasi (Teori dan Praktik) (p. 35). Bandung: Alfabeta.

Tangerang News. (2014). TangerangNews.com. Retrieved March 22, 2018, from http://tangerangnews.com/hiburan/read/11725/502-

Koperasi-di-Tangerang-Terancam-Dibubarkan

BPS Kota Tangerang. (2017). In Kota Tangerang Dalam Angka (p. 393). Tangerang: BPS Kota Tangerang.

TangerangNews.com. (2018). Koperasi di Kota Tangerang Tergerus Minimarket. Retrieved 06 09,
2018, from http://tangerangnews.com/kotatangerang/read/22975/Koperasi-di-Kota-TangerangTergerus-Minimarket 